\title{
High humidity alleviates photosynthetic inhibition and oxidative damage of tomato seedlings under heat stress
}

\author{
C. XU ${ }^{*, \dagger}$, Z.Q. YANG ${ }^{*, * *,+}$, S.Q. YANG ${ }^{*, \dagger}$, L. WANG ${ }^{*, \dagger}$, and M.T. WANG ${ }^{* * *, \#,+}$ \\ Collaborative Innovation Center on Forecast and Evaluation of Meteorological Disasters, Nanjing University \\ of Information Science and Technology, Nanjing, Jiangsu Province, China* \\ Binjiang College, Nanjing University of Information Science and Technology, Wuxi, China** \\ Sichuan Meteorological Observatory, Chengdu, Sichuan Province, China ${ }^{* * *}$ \\ Water-Saving Agriculture in Southern Hill Area Key Laboratory of Sichuan Province, Chengdu, Sichuan Province, \\ China ${ }^{\#}$
}

\begin{abstract}
This study investigated the effects of high humidity on the growth and photosynthetic and physiology traits of tomato plants under high temperature stress (HT). The results showed that high humidity effectively alleviated the limitation of HT on plant growth and increased the root-to-shoot ratio. In addition, high humidity also increased the chlorophyll content, net photosynthetic rate, and maximum photochemical quantum yield of PSII in tomato seedlings under HT stress, but declined the stomatal limitation value. Moreover, JIP-test showed that increasing air humidity improved the quantum yields and efficiencies of HT-stressed tomato plants and increased the size of functional antenna, while reduced the activity of a portion of reaction centers. Besides, high humidity increased the activity of antioxidant enzymes, but decreased the content of malondialdehyde and hydrogen peroxide in HT-stressed tomato plants. Therefore, high humidity improved the growth and alleviated photoinhibition and oxidative stress of tomato seedlings under heat stress.
\end{abstract}

Additional key words: chlorophyll fluorescence; Lycopersicon esculentum Mill.; photosynthesis.

\section{Introduction}

Tomato (Lycopersicon esculentum Mill.) is a widely grown vegetable crop in the greenhouse and its optimum growth temperature range is between 18 and $32^{\circ} \mathrm{C}$ (Berry and Björkman 1980, van der Ploeg and Heuvelink 2005). In summer and autumn greenhouses, the temperature tends to exceed this range, reaching above $35^{\circ} \mathrm{C}$, even above $40^{\circ} \mathrm{C}$; due to this fact the greenhouse infrastructure is lagging behind and has no precise temperature control systems in plastic greenhouses in northern China (Saeed et al. 2007, Pan et al. 2018). Therefore, high temperature
(HT) is considered to be one of the main environmental limiting factors that negatively affect the growth and productivity of tomato plants, especially in summer and autumn seasons.

HT stress generally means that the air temperature exceeds a certain critical threshold, which causes irreversible damage to the growth and development of plants after a period of time (Yusuf et al. 2010, Das et al. 2014). HT has an adverse effect on the growth parameters of tomato plants, such as plant height, stem diameter, leaf number, and vegetative biomass. Cruz-Ortega et al. (2002) showed that HT stress reduces the leaf emergence rate and

\footnotetext{
Received 23 June 2019, accepted 11 December 2019.

+Corresponding author; e-mail: yzq@nuist.edu.cn, wangmt0514@163.com

Abbreviations: ABS/RC - apparent antenna size of active PSII RC; AQE - apparent quantum efficiency; CAT - catalase; $C_{\mathrm{i}}-$ intercellular $\mathrm{CO}_{2}$ concentration; $\mathrm{DI}_{0} / \mathrm{RC}$ - effective dissipation of energy per active $\mathrm{RC} ; \mathrm{ET}_{0} / \mathrm{RC}$ - electron transport per active reaction center; $\mathrm{F}_{0}$ - minimal fluorescence yield of the dark-adapted state; $\mathrm{F}_{\mathrm{m}}$ - maximal fluorescence yield of the dark-adapted state; FM - fresh mass; $\mathrm{F}_{\mathrm{v}} / \mathrm{F}_{\mathrm{m}}$ - maximal quantum yield of PSII photochemistry; $g_{\mathrm{s}}$ - stomatal conductance; LCP - light-compensation point; $\mathrm{L}_{\mathrm{s}}-$ stomatal limitation value; LSP - light-saturation point; MDA - malondialdehyde; $\mathrm{PI}_{\text {abs }}$ - performance index on absorption basis; $\mathrm{PI}_{\text {total }}-$ total performance index; $P_{\mathrm{N}}$ - net photosynthetic rate; $P_{\mathrm{Nmax}}-$ maximum photosynthetic rate; POD - peroxidase; RC - reaction center; $\mathrm{RE}_{0} / \mathrm{RC}$ - electron flux reducing end electron acceptors at the PSI acceptor side per reaction center; SOD - superoxide dismutase; $\mathrm{TR}_{0} / \mathrm{RC}$ - trapped energy flux per reaction center; $\delta_{\mathrm{R} 0}-$ efficiency/probability with which an electron from the intersystem electron carriers moves to reduce end electron acceptors at the PSI acceptor side; $\varphi_{\mathrm{E} 0}$ - quantum yield for electron transport; $\varphi_{\mathrm{P} 0}-$ maximum quantum yield for primary photochemistry; $\varphi_{\mathrm{R} 0}$ - quantum yield for reduction of end electron acceptors at the PSI acceptor side. Acknowledgements: This work was supported by the National Natural Science Foundation of China (41975142 and 41775104); the National Key Research and Development Project of China (2019YFD1002202); the Foundation of Scientific and Technological Development of Meteorological Administration/Heavy Rain and Drought-Flood Disasters in Plateau and Basin Key Laboratory of Sichuan Province (Key Laboratory of Sichuan Province-2018-Key-05), and the Open Project Program of Key Laboratory of Agricultural Environment in Southwest mountain areas, Ministry of Agriculture and rural affairs, China (AESMA-OPP-2019006).

These authors contributed equally to this work.
} 
leaf area index, and also decreases the plant height and stem diameter in tomato plants. Peet et al. (1997) demonstrated that under HT stress, the carbon and nitrogen metabolism of tomato plants is imbalanced, and the elongation of petiole and stem consumes too much nutrients, resulting in a decrease in dry matter storage, which in turn affects the quality and yield of tomato. In addition to growth and biomass reduction, HT stress also induces the decline in photosynthesis of tomato plants before other physiological symptoms appear (Murkowski 2001). It is well known that HT stress causes the local electrical responses (LERs) (Sukhov et al. 2017) and the propagation of electrical signals (Fromm and Lautner 2007, Sukhov 2016), which, in turn, can affect photosynthesis (Sukhova et al. 2018 ), transpiration (Sukhov et al. 2015), respiration (Lautner et al. 2014), and ATP content (Surova et al. 2016) in leaves. Additionally, important photosynthetic processes, such as Chl synthesis, electron transport, and carbon dioxide assimilation process have been found very susceptible to HT stress in tomato plants (Camejo et al. 2005, Wu and Kubota 2008). For instance, tomato plants exposed to HT stress have a lower Chl content, cytochrome (Cyt) $b_{6} / f$, and plastocyanin (PC), as well as lower ATP synthase and Rubisco. Besides, HT stress often leads to excessive production of reactive oxygen species (ROS) and increases membrane lipid peroxidation in plants (Choudhury et al. 2013). ROS include molecules such as $\mathrm{H}_{2} \mathrm{O}_{2}$, ions such as $\mathrm{O}_{2}^{-}$, or radicals such as $\mathrm{OH}^{\circ}$, which can cause oxidative damage by causing disruption of membrane lipids, denaturation of proteins or destruction of DNA chain reactions, ultimately leading to cell death (Apel and Hirt 2004, Gill and Tuteja 2010). In order to control the effects of excessive ROS production in vitro and in vivo, plant cells activate photoprotection mechanisms. Antioxidant enzymes, such as catalase (CAT), peroxidase (POD), and superoxide dismutase (SOD), can effectively prevent ROS formation, scavenge the unavoidably formed ROS pool, and reduce the degree of membrane lipid peroxidation, thereby protecting plants from oxidative injury (Pukacka and Ratajczak 2005, Cruz de Carvalho 2008).

Chl fluorescence methods are considered to be one of the noninvasive, rapid, and easy ways for assessing the heat tolerance of plants (Pan et al. 2018). Referring to Chl fluorescence parameters, previous studies focused mainly on the maximal quantum yield of PSII photochemistry $\left(\mathrm{F}_{\mathrm{v}} / \mathrm{F}_{\mathrm{m}}\right)$ (Li et al. 2015) because it represents the photon energy absorbed by PSII for photochemical processes (Zaharieva and Dau 2019). However, the impairment of $\mathrm{Q}_{\mathrm{A}}$ energy flow caused by the reduced carboxylation or the decreased pool size of receptors cannot be reflected by $\mathrm{F}_{\mathrm{v}} / \mathrm{F}_{\mathrm{m}} . \mathrm{Chl} a$ fluorescence rise kinetics, from the initial 'O' to the 'P' (the peak) level, called OJIP kinetics, has become another way to evaluate the photosynthetic activity (Strasser et al. 1995). This analysis (Strasser et al. 2004, Tsimilli-Michael and Strasser 2008), referred as the 'JIP-test', allows us to obtain information on the structural and functional parameters that quantify the performance/ activity of the photosynthetic apparatus (for explanation, see 'Materials and methods' section, where the formulae and glossary of terms used by the JIP-test are presented).
More generally, the JIP-test has been widely used for evaluation of the effect of different types of abiotic stress, such as high or low temperature, drought, and heavy metals (Yusuf et al. 2010). Therefore, Chl fluorescence induction curves become a popular technique for detecting physiological state of plants under abiotic stress conditions.

Although high temperature has many adverse effects on plants, plants can reduce their leaf temperature through vigorous transpiration. The proper relative humidity level $(\mathrm{RH})$ can reduce leaf temperature and maintain stomatal conductance, maintaining the high yield via higher photosynthetic efficiency at high temperature (Han et al. 2019). Therefore, increasing air humidity is a common defensive measure to alleviate HT stress in facility production. Huang et al. (2010) showed that increasing the air humidity under HT conditions can increase the plant height, stem diameter, and leaf area growth of tomato plants, and significantly increase the yield and quality of greenhouse tomatoes in summer. Additionally, Barker (1990) pointed out that higher air humidity in the greenhouse for no more than $24 \mathrm{~h}$ significantly increased the stomatal conductance of tomato leaves, thereby improving the heat resistance of tomatoes. Furthermore, Wang et al. (2017) have shown that increasing the air humidity to $70 \%$ at $38^{\circ} \mathrm{C}$ significantly reduces the soluble sugar content in the roots and leaves of tomato seedlings, which is beneficial to the growth of tomato seedlings. However, there is little information to elucidate the effects of high humidity on photosynthetic characteristics and reactive oxygen metabolism in tomato plants under HT stress. In this study, we performed experiments (1) to compare the growth, biomass partitioning, $\mathrm{Chl}$ content, photosynthetic parameters, and antioxidant enzyme activities of tomato seedlings under different temperature regimes, and (2) to assess the effect of high humidity for mitigating the negative effect of HT stress, hoping to provide a simple, environmentally friendly, and effective method to alleviate the adverse effects of HT stress in the greenhouse.

\section{Materials and methods}

Plant material and experimental treatments: Venlo-type glasshouse of the Agricultural Meteorological Experiment Station, Nanjing University of Information Science and Technology (NUIST), Jiangsu province, China, was used to conduct the experiments. Tomato seedlings (Lycopersicon esculentum Mill., cv. 'JinGuan 5') with two leaves were grown in plastic pots filled with a peat:vermiculite mixture of 1:1 (v:v). Plants were drip-irrigated twice a day to prevent water stress with tap water and once every three days with water containing $\mathrm{N}$ fertilizer.

Uniform-sized tomato seedlings with eight true leaves were transferred to an artificial climate chamber (A1000, Conviron, Canada) with a temperature of $25 / 15^{\circ} \mathrm{C}$ (day/ night), photoperiod of 12/12 h (day/night), relative humidity of $50 \%$, and illumination intensity of $800 \mu \mathrm{mol}$ (photon) $\mathrm{m}^{-2} \mathrm{~s}^{-1}$ for $3 \mathrm{~d}$ to adapt to the environment. Then, all seedlings were divided into four groups with each group containing 40 pots. Two groups were subjected to a temperature of $25 / 15^{\circ} \mathrm{C}$ (day/night) with relative humidity of 50 and 
$70 \%$, respectively $\left[25 / 15^{\circ} \mathrm{C}+50 \%\left(\mathrm{~T}_{1} \mathrm{H}_{50}\right.\right.$, Control $)$ and $\left.25 / 15^{\circ} \mathrm{C}+70 \%\left(\mathrm{~T}_{1} \mathrm{H}_{70}\right)\right]$. The other two groups were subjected to $\mathrm{HT}$ treatment at $38 / 28^{\circ} \mathrm{C}$, and the relative humidity was set to 50 and $70 \%$, respectively $\left[38 / 28^{\circ} \mathrm{C}+\right.$ $50 \%\left(\mathrm{~T}_{2} \mathrm{H}_{50}\right)$ and $\left.38 / 28^{\circ} \mathrm{C}+70 \%\left(\mathrm{~T}_{2} \mathrm{H}_{70}\right)\right]$. The environmental conditions of each artificial climate chamber were as follows: photoperiod of $12 / 12 \mathrm{~h}$ (day/night) and illumination intensity of $800 \mu \mathrm{mol}$ (photon) $\mathrm{m}^{-2} \mathrm{~s}^{-1}$. Measurements were taken on 3, 6, 9, and $12 \mathrm{~d}$, respectively, and conducted on the fourth to sixth fully mature leaves.

Morphological index and biomass allocation: Plant height, stem diameter, and leaf area were measured by ruler, electronic vernier caliper, and leaf area meter (Model LI-3100A, Li-Cor, Inc., Lincoln, NE), respectively.

Tomato seedlings were harvested and partitioned into roots, leaves, and stems. Then plant fractions were ovendried at $85^{\circ} \mathrm{C}$ for $48 \mathrm{~h}$ and weighed using an electronic balance (ES-220D, China).

Photosynthetic pigment content: For Chl pigments measurement, leaf samples $(0.5 \mathrm{~g})$ were ground in a mortar with $2 \mathrm{ml}$ of $80 \%$ chilled acetone, centrifuged, and the supernatant was diluted to a final volume of $10 \mathrm{ml}$ with $80 \%$ acetone. Samples were extracted in darkness for $48 \mathrm{~h}$ at room temperature until pigments in the leaves were completely extracted. Absorbance values were measured at 645 and $663 \mathrm{~nm}$ by using the ultraviolet spectrophotometer (Cary 50 Conc UV-VIS, Varian, Victoria, Australia). The concentrations of Chl $a$ and Chl $b$ were determined according to the following formulas ( $\mathrm{Lu}$ et al. 2019): Chl $a\left[\mathrm{mg} \mathrm{g}^{-1}\right]=\left(12.72 \mathrm{~A}_{663}-2.59 \mathrm{~A}_{645}\right) \times \mathrm{V} /(1,000 \mathrm{~W})$, $\mathrm{Chl} b\left[\mathrm{mg} \mathrm{g}^{-1}\right]=\left(22.88 \mathrm{~A}_{645}-4.67 \mathrm{~A}_{663}\right) \times \mathrm{V} /(1,000 \mathrm{~W})$.

Chl fluorescence and gas-exchange parameters: Chl fluorescence parameters were measured using a Handy PEA fluorimeter (Hansatech Instruments Ltd., King's Lynn, UK). Minimal fluorescence $\left(\mathrm{F}_{0}\right)$, maximum fluorescence $\left(\mathrm{F}_{\mathrm{m}}\right)$, and maximum quantum yield of PSII $\left(\mathrm{F}_{\mathrm{v}} / \mathrm{F}_{\mathrm{m}}\right)$ were recorded automatically by exposing the leaves to actinic light of 3,500 $\mu \mathrm{mol}$ (photon) $\mathrm{m}^{-2} \mathrm{~s}^{-1}$ after $25 \mathrm{~min}$ of dark adaptation (Maxwell and Johnson 2000).

Then, thesameleaveswereused tomeasuregas-exchange parameters using the portable photosynthetic system, $L I$ 6400 (LI-COR Inc., USA), as described previously by $\mathrm{Su}$ et al. (2017). Net photosynthetic rate $\left(P_{\mathrm{N}}\right)$, stomatal conductance $\left(g_{\mathrm{s}}\right)$, and intercellular $\mathrm{CO}_{2}$ concentration $\left(C_{\mathrm{i}}\right)$ were automatically recorded by the $L I-6400$ program $(\mathrm{Xu}$ et al. 2019). The stomatal limit value $\left(\mathrm{L}_{\mathrm{s}}\right)$ was calculated by the equation $\mathrm{L}_{\mathrm{s}}=1-C_{\mathrm{i}} / C_{\mathrm{a}}$, where $\mathrm{C}_{\mathrm{a}}$ represents the atmospheric $\mathrm{CO}_{2}$ concentration. During the measurement, the light intensity, temperature, and $\mathrm{CO}_{2}$ concentration in the chamber were maintained at $800 \mu \mathrm{mol}$ (photon) $\mathrm{m}^{-2} \mathrm{~s}^{-1}$, $25^{\circ} \mathrm{C}$, and $390 \mu \mathrm{mol} \mathrm{mol}{ }^{-1}$, respectively. The relative humidity used during measurements by $L i-6400$ was the same as the humidity of each group to be treated. Each assayed leaf was light-induced with a light intensity of 800 $\mu \mathrm{mol}$ (photon) $\mathrm{m}^{-2} \mathrm{~s}^{-1}$ for $10 \mathrm{~min}$ before the measurement.
Light-response curve, OJIP curve, and JIP-test: The photosynthetic response curve was determined by using the portable photosynthetic system LI-6400 (LI-COR Inc., USA). During the measurement, the temperature of the leaf chamber was set at $25^{\circ} \mathrm{C}$, the concentration of $\mathrm{CO}_{2}$ was maintained at $390 \mu \mathrm{mol} \mathrm{mol}{ }^{-1}$, and the photosynthetic active radiation (PAR) was 1,$200 ; 1,000 ; 800,400,200$, $150,80,50,30$, and $0 \mu \mathrm{mol}\left(\right.$ photon) $\mathrm{m}^{-2} \mathrm{~s}^{-1}$, respectively. The relative humidity used during measurements in leaf chamber was the same as the humidity of each group to be treated.

In order to obtain accurately the parameters on the light-response curve, such as the light-compensation point (LCP), the light-saturation point (LSP), maximum net photosynthetic rate $\left(P_{\mathrm{Nmax}}\right)$, and the apparent quantum yield (AQE), it was necessary to fit the light-response curve. Light-response curves were simulated by a nonorthogonal hyperbolic model using SPSS 17.0 (SPSS Inc., Chicago, IL, USA) as described previously by Farquhar et al. (2001).

$$
P_{\mathrm{N}}(I)=\frac{\alpha I+P_{\max }-\left[\left(\alpha I+P_{\max }\right)^{2}-4 \theta \alpha I P_{\max }\right]^{0.5}}{2 \theta}-R_{\mathrm{d}}
$$

where, $P_{\mathrm{N}}(I)$ is the net photosynthetic rate, $I$ is the light intensity, $\theta$ is the curvature of the curve, and $\alpha$ is the slope of the plant photosynthesis $v s$. light-response curve at $I=0$, also called initial quantum efficiency, $P_{\max }$ is the maximum net photosynthetic rate, and $R_{\mathrm{d}}$ is the dark respiration rate.

The OJIP fluorescence transients $(10 \mu$ s to $1 \mathrm{~s})$ were monitored by Handy PEA fluorimeter as described in detail by Yusuf et al. (2010). Tomato leaves were darkacclimated for $20 \mathrm{~min}$ and then received continuous illumination $\left[3,500 \mu \mathrm{mol}\right.$ (photon) $\left.\mathrm{m}^{-2} \mathrm{~s}^{-1}\right]$ to measure fluorescence transients. The OJIP fluorescence transients were assayed using the JIP-test method (Zeliou et al. 2009). The JIP-test is a multiparametric analysis reflecting the structure and function of photosynthetic apparatus. For the detailed meaning of the JIP-test parameters involved in this article were calculated (Yusuf et al. 2010): (1) performance indexes: $\mathrm{PI}_{\mathrm{abs}}=(\mathrm{RC} / \mathrm{ABS}) \cdot\left[\varphi_{\mathrm{P} 0} /\left(1-\varphi_{\mathrm{P} 0}\right)\right]$ $\left[\varphi_{0} /\left(1-\varphi_{0}\right)\right], \mathrm{PI}_{\text {total }}=\mathrm{PI}_{\mathrm{abs}} \cdot\left[\mathrm{RE}_{0} /\left(\mathrm{ET}_{0}-\mathrm{RE}_{0}\right)\right] ;$ (2) quantum yields and efficiencies: $\varphi_{\mathrm{P}_{0}}=\mathrm{TP}_{0} / \mathrm{ABS}=\left[1-\left(\mathrm{F}_{0} / \mathrm{F}_{\mathrm{M}}\right)\right]$, $\varphi_{\mathrm{E} 0}=\mathrm{ET}_{0} / \mathrm{ABS}=\left[1-\left(\mathrm{F}_{0} / \mathrm{F}_{\mathrm{M}}\right)\right] \psi_{\mathrm{E} 0}, \varphi_{\mathrm{R} 0}=\mathrm{RE}_{0} / \mathrm{ABS}=$ $\left[1-\left(\mathrm{F}_{0} / \mathrm{F}_{\mathrm{M}}\right)\right] \psi_{\mathrm{E} 0} \delta_{\mathrm{R} 0}, \psi_{\mathrm{E} 0}=\mathrm{ET}_{0} / \mathrm{TP}_{0}=\left(1-\mathrm{V}_{\mathrm{J}}\right)$, and $\delta_{\mathrm{R} 0}=$ $\mathrm{RE}_{0} / \mathrm{ET}_{0}=\left(1-\mathrm{V}_{\mathrm{I}}\right) /\left(1-\mathrm{V}_{\mathrm{J}}\right)$; (3) energy fluxes: $\mathrm{ABS} / \mathrm{RC}=$ $\mathrm{M}_{0}\left(1 / \mathrm{V}_{\mathrm{j}}\right) \cdot\left(1 / \varphi_{\mathrm{Po}}\right), \quad \mathrm{TP}_{0} / \mathrm{RC}=\mathrm{M}_{0}\left(1 / \mathrm{V}_{\mathrm{j}}\right), \quad \mathrm{ET}_{0} / \mathrm{RC}=$ $\mathrm{M}_{0}\left(1 / \mathrm{V}_{\mathrm{j}}\right) \varphi_{0}$, and $\mathrm{RE}_{0} / \mathrm{RC}=\mathrm{M}_{0}\left(1 / \mathrm{V}_{\mathrm{J}}\right) \psi_{\mathrm{E} 0} \delta_{\mathrm{R} 0}$.

Antioxidant enzyme assays: The extraction of the enzyme solution was carried out using the method of Dhindsa and Matowe (1981) with slight modifications. Leaf samples of $2 \mathrm{~g}$ were ground in an ice bath with $10 \mathrm{ml}$ of phosphate buffer ( $\mathrm{pH} 7.8$ ), and centrifuged at $4,000 \times g$ for $25 \mathrm{~min}$ at $4^{\circ} \mathrm{C}$. The supernatant diluted to a final volume of $35 \mathrm{ml}$ with phosphate buffer ( $\mathrm{pH}$ 7.8) for the determination of antioxidant enzymes.

Catalase (CAT; EC 1.11.1.6) activity was assayed by potassium permanganate titration according to Huseynova (2012). Peroxidase (POD; EC 1.11.1.7) activity was 
measured by guaiacol chromogenic method based on the method of Rai et al. (2012). POD activity was expressed as $\mu \mathrm{mol}\left(\mathrm{H}_{2} \mathrm{O}_{2}\right.$ reduced) $\mathrm{min}^{-1} \mathrm{mg}^{-1}$ (protein). Superoxide dismutase (SOD; EC 1.15.1.1) activity was determined by nitroblue tetrazolium (NBT) method according to Ansari et al. (2018). SOD activity was expressed as U $\mathrm{mg}^{-1}$ (protein).

Malondialdehyde (MDA) and hydrogen peroxide $\left(\mathbf{H}_{2} \mathbf{O}_{2}\right)$ content: $\mathrm{H}_{2} \mathrm{O}_{2}$ content was determined using the method of Ansari et al. (2018). Leaf tissues (0.2 g) were homogenized in $5 \mathrm{ml}$ of $50 \mathrm{mM}$ sodium phosphate buffer (pH 6.5). Supernatant ( $3 \mathrm{ml}$ ) was mixed with $1 \mathrm{ml}$ of $0.1 \%$ (w/v) titanium sulfate in $20 \%(\mathrm{v} / \mathrm{v}) \mathrm{H}_{2} \mathrm{SO}_{4}$ and centrifuged for $25 \mathrm{~min}$ at $4,000 \times \mathrm{g}$. Absorbances of the supernatant were recorded at $410 \mathrm{~nm}$ with an ultraviolet spectrophotometer (Cary 50 Conc UV-VIS, Varian, Victoria, Australia).

MDA content was assayed by thiobarbituric acid reaction based on the method of Hodges et al. (1999) with minor modification. Leaf tissues $(0.1 \mathrm{~g})$ were homogenized in $1 \mathrm{ml}$ of $0.1 \%(\mathrm{v} / \mathrm{v})$ trichloroacetic acid containing $1 \%(\mathrm{w} / \mathrm{v})$ polyvinylpyrrolidone (PVP), and $0.5 \%(\mathrm{v} / \mathrm{v})$ butylated hydroxytoluene. The supernatant reacted with $20 \%$ thiobarbituric acid, then absorbance values of the supernatant were read at 440, 532, and $600 \mathrm{~nm}$ by using the spectrophotometer (Cary 50 Conc UV-VIS, Varian, Victoria, Australia). MDA content [nmol g-1(FM)] was calculated.

Statistical procedures: All data were analyzed using the statistical package SPSS 17.0 (SPSS, Chicago, IL, USA). One-way analysis of variance (ANOVA) followed by Duncan's multiple range test (at $P=0.05$ ) was used to assess the differences between treatments. All figures were drawn by using the GraphPad Prism 7.05 (GraphPad Software, San Diego, CA, USA). The results of the measured parameters were presented as the mean \pm standard deviation (SD) of five biological replications, with three samples of each replication.

\section{Results}

Growth parameters: HT and HH stress were reflected in the morphological indices, the photosynthetic pigments, and the biomass allocation (Table $1 \mathrm{~S}$, supplement). Compared to those of the CK group, the daily height increment, daily stem diameter increment, and daily leaf area increment of tomato seedlings were inhibited under $\mathrm{T}_{1} \mathrm{H}_{70}$. Similar to the $\mathrm{T}_{1} \mathrm{H}_{70}$ group, these parameters decreased significantly by $11.9,35$, and $18.5 \%$ in $\mathrm{T}_{2} \mathrm{H}_{50}$ group, but under $\mathrm{T}_{2} \mathrm{H}_{70}$ conditions, these indices improved significantly by 8.1 , 46.2 , and $15.9 \%$, respectively. Similarly, the contents of $\mathrm{Chl} a$ and $\mathrm{Chl} b$ in the $\mathrm{T}_{1} \mathrm{H}_{70}$ and $\mathrm{T}_{2} \mathrm{H}_{50}$ groups were lower than those of the CK group. However, these two indices increased by 5 and $10 \%$, respectively, under $\mathrm{T}_{2} \mathrm{H}_{70}$ group. HT stress also adversely affected the root DM, shoot DM, and root-to-shoot ratio, which decreased by $41.9,2.8$, and $29.4 \%$, respectively, compared to those of nonstressed tomato seedlings, whereas those parameters significantly increased by $36.3,1.4$, and $25 \%$, respectively, under $\mathrm{T}_{2} \mathrm{H}_{70}$ conditions.

Gas-exchange parameters and light-response curves: $\mathrm{HH}$ and HT stress had a negative impact on gas-exchange parameters (Fig. 1). Compared to the control group, the $P_{\mathrm{N}}, C_{\mathrm{i}}$, and $g_{\mathrm{s}}$ in $\mathrm{T}_{2} \mathrm{H}_{50}$ group were reduced significantly,

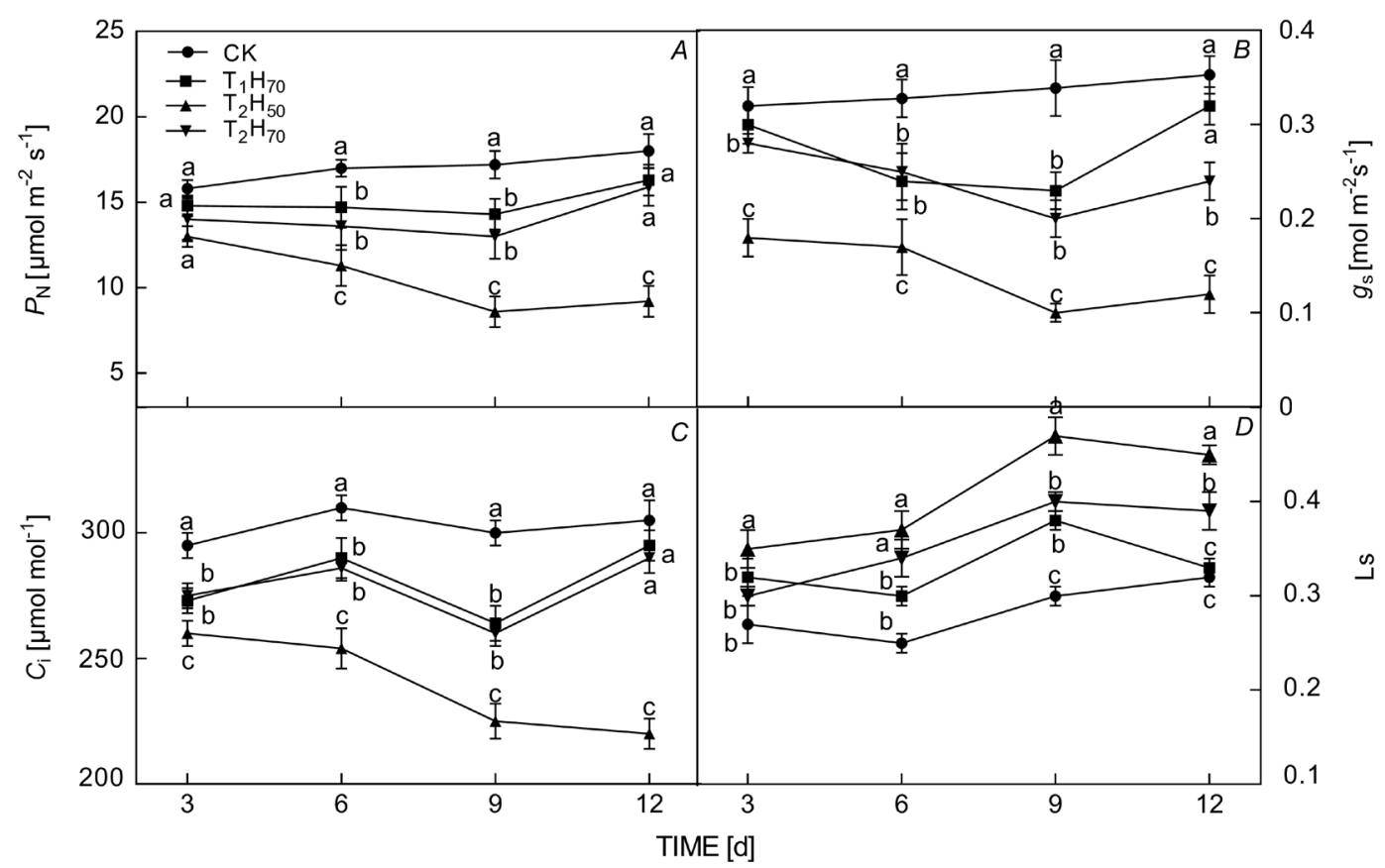

Fig. 1. Effects of high humidity on the net photosynthetic rate $\left(P_{\mathrm{N}}\right)(A)$, stomatal conductance $\left(g_{\mathrm{s}}\right)(B)$, intercellular $\mathrm{CO}_{2}$ concentration $\left(C_{\mathrm{i}}\right)(C)$, and stomatal limitation value $\left(\mathrm{L}_{\mathrm{s}}\right)(D)$ in tomato leaves under HT stress. Different lowercase letters in the same time represent significant differences at the level of 0.05 by Duncan's multiple range tests. Values are means $\pm \mathrm{SD}, n=15$. CK $-25 / 15^{\circ} \mathrm{C}+50 \%$ relative humidity (RH); $\mathrm{T}_{1} \mathrm{H}_{70}-25 / 15^{\circ} \mathrm{C}+70 \% \mathrm{RH} ; \mathrm{T}_{2} \mathrm{H}_{50}-38 / 28^{\circ} \mathrm{C}+50 \% \mathrm{RH} ; \mathrm{T}_{2} \mathrm{H}_{70}-38 / 28^{\circ} \mathrm{C}+70 \% \mathrm{RH}$. 
but the $\mathrm{L}_{\mathrm{s}}$ increased significantly. However, high humidity significantly mitigated the effects of high temperatures on gas-exchange parameters, with a marked improvement of $P_{\mathrm{N}}, C_{\mathrm{i}}$, and $g_{\mathrm{s}}$ in $\mathrm{T}_{2} \mathrm{H}_{70}$ group, and a significant reduction in the value of $\mathrm{L}_{\mathrm{s}}$ in $\mathrm{T}_{2} \mathrm{H}_{70}$ group.

Furthermore, four rapid light curves of $P_{\mathrm{N}}$ in the range from 0 to $1,400 \mu$ mol(photon) $\mathrm{m}^{-2} \mathrm{~s}^{-1}$ were used to investigate the photosynthetic capacity of the tomato plants (Fig. 2). The $P_{\mathrm{N}}$ increased with the increase of PAR. The upper curve $\left(\mathrm{T}_{1} \mathrm{H}_{50}\right)$ showed the highest $P_{\mathrm{N}}$, while $P_{\mathrm{N}}$ under $\mathrm{T}_{1} \mathrm{H}_{70}, \mathrm{~T}_{2} \mathrm{H}_{50}$, and $\mathrm{T}_{2} \mathrm{H}_{70}$ were $87.5,62.4$, and $81.3 \%$ of the control, respectively, when the light intensity reached $1,400 \mu \mathrm{mol}$ (photon) $\mathrm{m}^{-2} \mathrm{~s}^{-1}$.

$\mathrm{HH}$ and HT stress reduced the $P_{\mathrm{N} \max }, \mathrm{AQE}$, and LSP of tomato seedlings, which were $15.42 \mu \mathrm{mol} \mathrm{m}^{-2} \mathrm{~s}^{-1}, 0.04$, and $756.64 \mu \mathrm{mol} \mathrm{m}^{-2} \mathrm{~s}^{-1}$ in $\mathrm{T}_{1} \mathrm{H}_{70}$ group; $11.79 \mu \mathrm{mol} \mathrm{m}^{-2} \mathrm{~s}^{-1}$, 0.032 , and $521.36 \mu \mathrm{mol} \mathrm{m} \mathrm{m}^{-2} \mathrm{~s}^{-1}$ in $\mathrm{T}_{2} \mathrm{H}_{50}$ group; whereas were $15.25 \mu \mathrm{mol} \mathrm{m}^{-2} \mathrm{~s}^{-1}, 0.041$, and $764.44 \mu \mathrm{mol} \mathrm{m}^{-2} \mathrm{~s}^{-1}$ in $\mathrm{T}_{2} \mathrm{H}_{70}$ group, respectively (Table 1 ). In addition, the value of LCP in $\mathrm{T}_{2} \mathrm{H}_{50}$ group significantly increased by $21.5 \%$ compared to the control, but significantly declined by $14.7 \%$ compared with that in the $\mathrm{T}_{2} \mathrm{H}_{70}$ group.

Chl fluorescence parameters, OJIP curve, and JIP-test: As can be seen from Table 2, the values of $F_{v} / F_{m}$ and $F_{m}$ were significantly reduced by 13.3 and $34.5 \%$ in $\mathrm{T}_{2} \mathrm{H}_{50}$

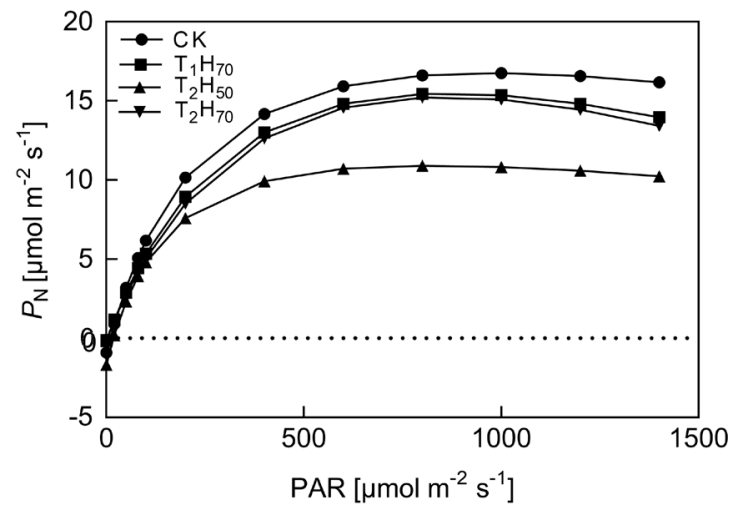

Fig. 2. Effects of high humidity on light-response curves in tomato leaves under HT stress on the $12^{\text {th }}$ day of treatment. $P_{\mathrm{N}}-$ net photosynthetic rate. $\mathrm{CK}-25 / 15^{\circ} \mathrm{C}+50 \%$ relative humidity $(\mathrm{RH}) ; \mathrm{T}_{1} \mathrm{H}_{70}-25 / 15^{\circ} \mathrm{C}+70 \% \mathrm{RH} ; \mathrm{T}_{2} \mathrm{H}_{50}-38 / 28^{\circ} \mathrm{C}+50 \% \mathrm{RH}$; $\mathrm{T}_{2} \mathrm{H}_{70}-38 / 28^{\circ} \mathrm{C}+70 \% \mathrm{RH}$. group, respectively, but the $\mathrm{F}_{0}$ increased significantly by $30 \%$. High humidity led to a significant increase in $F_{v} / F_{m}$ and $\mathrm{F}_{\mathrm{m}}$ under heat stress, but still 4.8 and $13.8 \%$ lower than that of the control, respectively. Additionally, the $\mathrm{F}_{0}$ significantly decreased by $22.4 \%$ under $\mathrm{T}_{2} \mathrm{H}_{70}$ conditions compared to the $\mathrm{T}_{2} \mathrm{H}_{50}$ group.

The shape of the OJIP curve was also influenced by HT and $\mathrm{HH}$ stress (Fig. 3). The relative variable fluorescence of $\mathrm{O}-\mathrm{J}, \mathrm{J}-\mathrm{I}$, and $\mathrm{I}-\mathrm{P}$ phases in the $\mathrm{T}_{2} \mathrm{H}_{50}$ group was significantly higher than that in the control group. The relative variable fluorescence at the $\mathrm{O}-\mathrm{J}$ and $\mathrm{J}-\mathrm{I}$ phases effectively decreased at $\mathrm{T}_{2} \mathrm{H}_{70}$ group compared to the $\mathrm{T}_{2} \mathrm{H}_{50}$ group, but showed no difference from the $\mathrm{T}_{2} \mathrm{H}_{50}$ group in the I-P phase. The JIP-test analysis demonstrated that the values of $\varphi_{\mathrm{P} 0}, \varphi_{\mathrm{E} 0}, \delta_{\mathrm{R} 0}, \varphi_{\mathrm{R} 0}, \mathrm{ET}_{0} / \mathrm{RC}$, and $\mathrm{RE}_{0} / \mathrm{RC}$ in the $\mathrm{T}_{2} \mathrm{H}_{50}$ group were significantly reduced by $13.8,23.7$, $30.6,42.9,21.7$, and $45.5 \%$, respectively, compared to those in the control group (Table 3). However, those values effectively increased by $4.9,28.9,40.0,58.3,31.4$, and $45.5 \%$, respectively, int $\mathrm{T}_{2} \mathrm{H}_{70}$ group. In addition, the values of $\mathrm{ABS} / \mathrm{RC}, \mathrm{DI}_{0} / \mathrm{RC}$, and $\mathrm{TP}_{0} / \mathrm{RC}$ also increased by 3.0 , 50.0 , and $11.1 \%$, respectively, in $\mathrm{T}_{2} \mathrm{H}_{50}$ group compared to those in the control group, while those values significantly mitigated by $3.0,10.0$, and $6.2 \%$, respectively, in $\mathrm{T}_{2} \mathrm{H}_{70}$ group. Meanwhile, HT stress had an adverse effect on $\mathrm{PI}_{\text {abs }}$ and $\mathrm{PI}_{\text {total }}$, which significantly decreased by 56.7 and $74.2 \%$, respectively, compared with the control group. In contrast, high humidity increased them under HT stress 2.07 times and 3.52 times, respectively, compared to the HT stress group.

Lipid peroxidation assay and ROS metabolism: $\mathrm{HH}$ and HT stress significantly increased the contents of MDA and $\mathrm{H}_{2} \mathrm{O}_{2}$ in leaves of tomato plants (Table 4). Compared to the control group, MDA and $\mathrm{H}_{2} \mathrm{O}_{2}$ contents progressively increased by 100.0 and $91.7 \%$, respectively, in $\mathrm{T}_{2} \mathrm{H}_{50}$ group. The content of MDA was significantly reduced by $25 \%$ in $\mathrm{T}_{2} \mathrm{H}_{70}$ group compared to the HT stress tomato seedlings. MDA content under $\mathrm{T}_{2} \mathrm{H}_{70}$ group was $33.3 \%$ higher than that of the control group, but no significant differences between them were found. In addition, the content of $\mathrm{H}_{2} \mathrm{O}_{2}$ significantly decreased by $21.7 \%$ in $\mathrm{T}_{2} \mathrm{H}_{70}$ group compared to that in the $\mathrm{T}_{2} \mathrm{H}_{50}$ group.

Furthermore, HT stress increased the activity of SOD, CAT, and POD, which was significantly higher than that in

Table 1. Effects of high humidity on photosynthetic parameters of tomato seedlings under HT stress on the $12^{\text {th }}$ day of treatment. Different lowercase letters in the same column represent significant differences at the level of 0.05 by Duncan's multiple range tests. Values are means $\pm \mathrm{SD}, n=15 . P_{\mathrm{Nmax}}-$ maximum photosynthetic rate; AQE - apparent quantum efficiency; LCP - light-compensation point; $\mathrm{LSP}$ - light-saturation point. $\mathrm{CK}-25 / 15^{\circ} \mathrm{C}+50 \%$ relative humidity $(\mathrm{RH}) ; \mathrm{T}_{1} \mathrm{H}_{70}-25 / 15^{\circ} \mathrm{C}+70 \% \mathrm{RH} ; \mathrm{T}_{2} \mathrm{H}_{50}-38 / 28^{\circ} \mathrm{C}+50 \% \mathrm{RH}$; $\mathrm{T}_{2} \mathrm{H}_{70}-38 / 28^{\circ} \mathrm{C}+70 \% \mathrm{RH}$.

\begin{tabular}{|c|c|c|c|c|}
\hline Treatment & 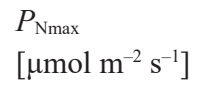 & $\mathrm{AQE}$ & $\begin{array}{l}\mathrm{LCP} \\
{\left[\mu \mathrm{mol} \mathrm{m}{ }^{-2} \mathrm{~s}^{-1}\right]}\end{array}$ & $\begin{array}{l}\text { LSP } \\
{\left[\mu \mathrm{mol} \mathrm{m}{ }^{-2} \mathrm{~s}^{-1}\right]}\end{array}$ \\
\hline $\mathrm{T}_{1} \mathrm{H}_{50}, \mathrm{CK}$ & $16.76 \pm 0.22^{\mathrm{a}}$ & $0.049 \pm 0.002^{\mathrm{a}}$ & $8.71 \pm 0.19^{\mathrm{a}}$ & $964.75 \pm 21^{\mathrm{a}}$ \\
\hline $\mathrm{T}_{1} \mathrm{H}_{70}$ & $15.42 \pm 0.32^{\mathrm{a}}$ & $0.040 \pm 0.001^{\mathrm{b}}$ & $9.33 \pm 0.13^{\mathrm{b}}$ & $756.64 \pm 13^{b}$ \\
\hline $\mathrm{T}_{2} \mathrm{H}_{50}$ & $8.79 \pm 0.20^{\mathrm{c}}$ & $0.032 \pm 0.002^{\mathrm{c}}$ & $10.58 \pm 0.20^{c}$ & $521.36 \pm 24^{\mathrm{c}}$ \\
\hline $\mathrm{T}_{2} \mathrm{H}_{70}$ & $15.25 \pm 0.21^{\mathrm{b}}$ & $0.041 \pm 0.003^{b}$ & $9.23 \pm 0.15^{\mathrm{b}}$ & $764.44 \pm 20^{\mathrm{b}}$ \\
\hline
\end{tabular}


Table 2. Effects of high humidity on maximal quantum yield of PSII photochemistry $\left(\mathrm{F}_{\mathrm{v}} / \mathrm{F}_{\mathrm{m}}\right)$, minimal fluorescence yield of the dark-adapted state $\left(\mathrm{F}_{0}\right)$, and maximal fluorescence yield of the dark-adapted state $\left(\mathrm{F}_{\mathrm{m}}\right)$ in tomato leaves under HT stress on the $12^{\text {th }}$ day of treatment. Different lowercase letters in the same column represent significant differences at the level of 0.05 by Duncan's multiple range tests. Values are means $\pm \mathrm{SD}, n=15$. $\mathrm{CK}-25 / 15^{\circ} \mathrm{C}+50 \%$ relative humidity $(\mathrm{RH}) ; \mathrm{T}_{1} \mathrm{H}_{70}-25 / 15^{\circ} \mathrm{C}+$ $70 \% \mathrm{RH} ; \mathrm{T}_{2} \mathrm{H}_{50}-38 / 28^{\circ} \mathrm{C}+50 \% \mathrm{RH} ; \mathrm{T}_{2} \mathrm{H}_{70}-38 / 28^{\circ} \mathrm{C}+70 \% \mathrm{RH}$.

\begin{tabular}{llll}
\hline Treatment & $\mathrm{F}_{\mathrm{v}} / \mathrm{F}_{\mathrm{m}}$ & $\mathrm{F}_{0}$ & $\mathrm{~F}_{\mathrm{m}}$ \\
\hline $\mathrm{T}_{1} \mathrm{H}_{50}, \mathrm{CK}$ & $0.83 \pm 0.21^{\mathrm{a}}$ & $0.45 \pm 0.02^{\mathrm{c}}$ & $2.9 \pm 0.13^{\mathrm{a}}$ \\
$\mathrm{T}_{1} \mathrm{H}_{70}$ & $0.81 \pm 0.11^{\mathrm{a}}$ & $0.48 \pm 0.01^{\mathrm{c}}$ & $2.6 \pm 0.10^{\mathrm{b}}$ \\
$\mathrm{T}_{2} \mathrm{H}_{50}$ & $0.72 \pm 0.12^{\mathrm{b}}$ & $0.67 \pm 0.05^{\mathrm{a}}$ & $1.9 \pm 0.21^{\mathrm{c}}$ \\
$\mathrm{T}_{2} \mathrm{H}_{70}$ & $0.79 \pm 0.20^{\mathrm{a}}$ & $0.52 \pm 0.02^{\mathrm{b}}$ & $2.5 \pm 0.12^{\mathrm{b}}$ \\
\hline
\end{tabular}

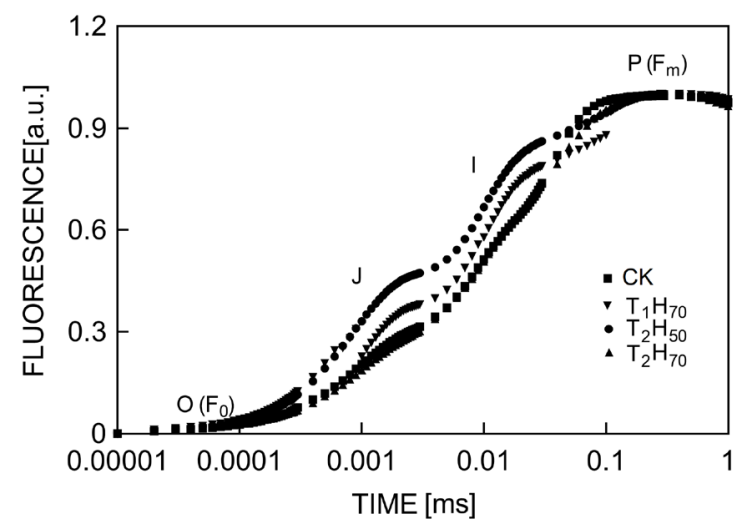

Fig. 3. Effects of high humidity on the performance of chlorophyll $a$ fluorescence induction curves in tomato leaves under HT stress on the $12^{\text {th }}$ day of treatment. $\mathrm{O}$ - initial fluorescence; $\mathrm{J}$ - intermediate level at $2 \mathrm{~ms}$; I - intermediate level at $30 \mathrm{~ms}$; $\mathrm{P}$ - peak level from $50 \mathrm{~ms}$ to $1 \mathrm{~s}$. $\mathrm{CK}-25 / 15^{\circ} \mathrm{C}+50 \%$ relative humidity (RH); $\mathrm{T}_{1} \mathrm{H}_{70}-25 / 15^{\circ} \mathrm{C}+70 \% \mathrm{RH} ; \mathrm{T}_{2} \mathrm{H}_{50}-38 / 28^{\circ} \mathrm{C}+$ $50 \% \mathrm{RH} ; \mathrm{T}_{2} \mathrm{H}_{70}-38 / 28^{\circ} \mathrm{C}+70 \% \mathrm{RH}$.

the control group (Fig. 4). However, high humidity led to a significant reduction of SOD, CAT, and POD activities under heat stress compared to the $\mathrm{T}_{2} \mathrm{H}_{50}$ group, although the SOD, CAT, and POD activities were still higher than that in the nonstressed tomato seedlings in all the treatments.

\section{Discussion}

The RH plays an important role in plants growth. On one hand, it can interact with other external factors, such as temperature, soil moisture, and soil nutrient. On the other hand, it can affect many physiological processes, such as photosynthesis, transpiration, and the mineral uptake of the plant (Han et al. 2019).

In general, under HT stress, the photosynthetic function of plant leaves is reduced, and the transport and distribution of organic matter are in disorder, leading to premature senescence of leaves, resulting in poor growth and development of plants (Krishnan et al. 2011). Changes in plant biomass are also responses to adverse stresses (Shu et al. 2016). In this study, it was clear that the growth and development of tomato seedlings were inhibited after HT treatments, which was characterized by slower daily increment of height, stem diameter, and leaf area, and lower root-to-shoot ratio, while high humidity treatment could alleviate the symptoms brought by HT stress, indicating that increasing the air humidity maintains the normal transmission and distribution of tomato photosynthetic products, and ensures the growth and development of plants under HT stress. This result can be confirmed by Wang et al. (2018); high humidity can increase the soluble sugar content in leaves, stems, and roots of tomato seedlings under HT stress compared with the control.

Chloroplasts are the main site for photosynthetic reactions and are also sensitive to HT stress (Tang et al. 2006, Marečková et al. 2019). The Chl content often reflects the chloroplast development and photosynthetic performance (Lu et al. 2019). In our study, HT stress significantly reduced the contents of Chl $a$ and $\mathrm{Chl} b$, probably because the high temperature severely damaged the structure and function of Chl, or significantly increased the activity of Chl-degrading enzymes. The results of this study have also been confirmed on spring wheat (Prasad et al. 2011), potato plants (Tang et al. 2006), etc. Moreover, high humidity can effectively alleviate the damage of Chl-containing structure and function by HT stress, and maintain photosynthetic capacity of chloroplasts at high temperatures (Table 1S). Early studies suggested that the decrease in photosynthetic rate was due to the decrease of leaf $g_{\mathrm{s}}$, which hindered the supply of $\mathrm{CO}_{2}$ in chloroplasts caused by stomatal limitation factors (Muraoka et al. 2000). However, Su and Liu (2005), Yan et al. (2011), and other studies believe that the inhibition of photosynthesis by HT is caused by nonstomatal factors, which is caused by the increase of gas diffusion resistance of mesophyll cells, the decrease of $\mathrm{CO}_{2}$ solubility, and the decrease of Rubisco affinity for $\mathrm{CO}_{2}$. This experiment showed that under HT treatment, $P_{\mathrm{N}}$ decreased in tomato leaves, accompanied by different decline of $g_{\mathrm{s}}$ and $C_{\mathrm{i}}$, and $\mathrm{L}_{\mathrm{s}}$ increased significantly (Fig. 1), which indicated that the decrease of $P_{\mathrm{N}}$ in tomato leaves may be the effect of stomatal limitation. However, by increasing the humidity of the air, the $P_{\mathrm{N}}$ of tomato seedlings can be increased and the values of $\mathrm{L}_{\mathrm{s}}$ can be reduced under high temperatures. In addition, HT also significantly influenced the photosynthetic curve parameters of tomato seedlings, such as significantly reduced the $P_{\mathrm{N} \max }, \mathrm{AQE}$, and LCP, and significantly increased the LSP (Table 1), which was consistent with the research results of Zhou et al. (2015), but high humidity can effectively alleviate the influence of HT stress on the characteristic parameters of light-response curve.

The $\mathrm{PI}_{\text {total }}$ is an index of photosynthetic performance, and is also closely related to the ultimate life state of the plants, such as growth and development under stress conditions (Yusuf et al. 2010). A negative value for $\mathrm{PI}_{\text {total }}$ indicates 'loss' and a positive value indicates 'gain' for energy conservation. HT significantly reduced the value of $\mathrm{PI}_{\text {total }}$ compared to the control group, but high humidity can alleviate the decrease in the $\mathrm{PI}_{\text {total }}$ value (Table 3), which means that there was a 'loss' of energy conservation after 
Table 3. Effects of high humidity on JIP-test parameters in tomato leaves under HT stress on the $12^{\text {th }}$ day of treatment. Different lowercase letters in the same column represent significant differences at the level of 0.05 by Duncan's multiple range tests. Values are means \pm SD, $n=15 . \mathrm{ABS} / \mathrm{RC}-$ apparent antenna size of active PSII per reaction center; $\mathrm{DI}_{0} / \mathrm{RC}$ - effective dissipation of energy per active $\mathrm{RC}$; $\mathrm{TR}_{0} / \mathrm{RC}$ - trapped energy flux per reaction center; $\mathrm{ET}_{0} / \mathrm{RC}$ - electron transport flux per reaction center; $\mathrm{RE}_{0} / \mathrm{RC}$ - electron flux reducing end electron acceptors at the PSI acceptor side per reaction center; $\varphi_{\mathrm{P} 0}-$ maximum quantum yield for primary photochemistry; $\varphi_{\mathrm{E} 0}-$ quantum yield for electron transport; $\delta_{\mathrm{R} 0}-$ efficiency/probability with which an electron from the intersystem electron carriers moves to reduce end electron acceptors at the PSI acceptor side; $\varphi_{\mathrm{R} 0}$ - quantum yield for reduction of end electron acceptors at the PSI acceptor side; $\mathrm{PI}_{\text {abs }}$ - performance index (potential) for energy conservation from exciton to the reduction of intersystem electron acceptors; $\mathrm{PI}_{\text {total }}$ - performance index (potential) for energy conservation from exciton to the reduction of PSI end acceptors. $\mathrm{CK}-25 / 15^{\circ} \mathrm{C}+50 \%$ relative humidity $(\mathrm{RH}) ; \mathrm{T}_{1} \mathrm{H}_{70}-25 / 15^{\circ} \mathrm{C}+70 \% \mathrm{RH} ; \mathrm{T}_{2} \mathrm{H}_{50}-38 / 28^{\circ} \mathrm{C}+50 \% \mathrm{RH} ; \mathrm{T}_{2} \mathrm{H}_{70}-38 / 28^{\circ} \mathrm{C}+70 \% \mathrm{RH}$.

\begin{tabular}{lllll}
\hline Parameter & $\mathrm{T}_{1} \mathrm{H}_{50}, \mathrm{CK}$ & $\mathrm{T}_{1} \mathrm{H}_{70}$ & $\mathrm{~T}_{2} \mathrm{H}_{50}$ & $\mathrm{~T}_{2} \mathrm{H}_{70}$ \\
\hline $\mathrm{ABS} / \mathrm{RC}$ & $1.01 \pm 0.01^{\mathrm{c}}$ & $1.03 \pm 0.01^{\mathrm{b}}$ & $1.04 \pm 0.01^{\mathrm{a}}$ & $1.03 \pm 0.01^{\mathrm{a}}$ \\
$\mathrm{DI}_{0} / \mathrm{RC}$ & $0.40 \pm 0.03^{\mathrm{c}}$ & $0.44 \pm 0.01^{\mathrm{b}}$ & $0.60 \pm 0.02^{\mathrm{a}}$ & $0.45 \pm 0.01^{\mathrm{b}}$ \\
$\mathrm{TR}_{0} / \mathrm{RC}$ & $0.81 \pm 0.01^{\mathrm{c}}$ & $0.84 \pm 0.02^{\mathrm{b}}$ & $0.90 \pm 0.03^{\mathrm{a}}$ & $0.86 \pm 0.02^{\mathrm{b}}$ \\
$\mathrm{ET}_{0} / \mathrm{RC}$ & $0.60 \pm 0.03^{\mathrm{a}}$ & $0.58 \pm 0.02^{\mathrm{a}}$ & $0.47 \pm 0.05^{\mathrm{b}}$ & $0.62 \pm 0.02^{\mathrm{a}}$ \\
$\mathrm{RE}_{0} / \mathrm{RC}$ & $0.22 \pm 0.02^{\mathrm{a}}$ & $0.20 \pm 0.01^{\mathrm{a}}$ & $0.12 \pm 0.01^{\mathrm{b}}$ & $0.22 \pm 0.01^{\mathrm{a}}$ \\
$\varphi \mathrm{P}_{\mathrm{o}}$ & $0.94 \pm 0.01^{\mathrm{a}}$ & $0.90 \pm 0.02^{\mathrm{b}}$ & $0.81 \pm 0.01^{\mathrm{d}}$ & $0.85 \pm 0.01^{\mathrm{c}}$ \\
$\varphi \mathrm{E}_{\mathrm{o}}$ & $0.59 \pm 0.02^{\mathrm{a}}$ & $0.57 \pm 0.01^{\mathrm{a}}$ & $0.45 \pm 0.01^{\mathrm{b}}$ & $0.58 \pm 0.02^{\mathrm{a}}$ \\
$\delta \mathrm{R}_{\mathrm{o}}$ & $0.36 \pm 0.03^{\mathrm{a}}$ & $0.36 \pm 0.01^{\mathrm{a}}$ & $0.25 \pm 0.01^{\mathrm{b}}$ & $0.35 \pm 0.02^{\mathrm{a}}$ \\
$\varphi \mathrm{R}_{o}$ & $0.21 \pm 0.03^{\mathrm{a}}$ & $0.20 \pm 0.01^{\mathrm{a}}$ & $0.12 \pm 0.01^{\mathrm{b}}$ & $0.19 \pm 0.01^{\mathrm{a}}$ \\
$\mathrm{PI}_{\text {abs }}$ & $11.38 \pm 0.46^{\mathrm{a}}$ & $10.11 \pm 0.21^{\mathrm{b}}$ & $4.96 \pm 0.54^{\mathrm{c}}$ & $10.25 \pm 0.67^{\mathrm{b}}$ \\
$\mathrm{PI}_{\text {total }}$ & $6.36 \pm 0.39^{\mathrm{a}}$ & $4.93 \pm 0.01^{\mathrm{c}}$ & $1.64 \pm 0.36^{\mathrm{d}}$ & $5.78 \pm 0.56^{\mathrm{b}}$ \\
\hline
\end{tabular}

Table 4. Effects of high humidity on malondialdehyde (MDA) and $\mathrm{H}_{2} \mathrm{O}_{2}$ contents in tomato leaves under HT stress on the $12^{\text {th }}$ day of treatment. Different lowercase letters in the same column represent significant differences at the level of 0.05 by Duncan's multiple range tests. Values are means $\pm \mathrm{SD}, n=15$. $\mathrm{CK}-25 / 15^{\circ} \mathrm{C}+50 \%$ relative humidity $(\mathrm{RH}) ; \mathrm{T}_{1} \mathrm{H}_{70}-25 / 15^{\circ} \mathrm{C}+70 \% \mathrm{RH} ; \mathrm{T}_{2} \mathrm{H}_{50}-$ $38 / 28^{\circ} \mathrm{C}+50 \% \mathrm{RH} ; \mathrm{T}_{2} \mathrm{H}_{70}-38 / 28^{\circ} \mathrm{C}+70 \% \mathrm{RH}$.

\begin{tabular}{lll}
\hline Treatment & MDA content $\left[\mathrm{nmol} \mathrm{g}^{-1}(\mathrm{FM})\right]$ & $\mathrm{H}_{2} \mathrm{O}_{2}$ content $\left[\mu \mathrm{mol} \mathrm{g}{ }^{-1}(\mathrm{FM})\right]$ \\
\hline $\mathrm{T}_{1} \mathrm{H}_{50}, \mathrm{CK}$ & $0.62 \pm 0.21^{\mathrm{c}}$ & $1.63 \pm 0.22^{\mathrm{b}}$ \\
$\mathrm{T}_{1} \mathrm{H}_{70}$ & $0.82 \pm 0.22^{\mathrm{c}}$ & $1.74 \pm 0.11^{\mathrm{b}}$ \\
$\mathrm{T}_{2} \mathrm{H}_{50}$ & $1.24 \pm 0.14^{\mathrm{a}}$ & $2.32 \pm 0.30^{\mathrm{a}}$ \\
$\mathrm{T}_{2} \mathrm{H}_{70}$ & $0.93 \pm 0.24^{\mathrm{b}}$ & $1.84 \pm 0.21^{\mathrm{b}}$ \\
\hline
\end{tabular}

HT stress, and an increase was observed after increasing the air humidity. The Chl fluorescence signal and its calculated parameters were successfully applied to detect the injury of PSII in plants under different environmental stresses (Krause and Weis 1991, Maxwell and Johnson 2000). $\mathrm{F}_{\mathrm{v}} / \mathrm{F}_{\mathrm{m}}$ is the maximum photochemical quantum yield of PSII, reflecting the intrinsic conversion efficiency of PSII reaction center. Under nonstress conditions, the variation of this parameter is very small, and it is not affected by species and growth conditions, but under stress conditions, the parameter decreases significantly (Baker 2008). In our study, the $F_{\mathrm{v}} / \mathrm{F}_{\mathrm{m}}$ decreased significantly at the HT stress, indicating the energy converted into chemical fixation was reduced, while that used for heat dissipation increased (van Kooten and Snel 1990, Baker 2008). In addition, the increase in both $F_{0}$ and $F_{m}$ (Table 2), which implied the electron transfer was blocked from the primary acceptor $\mathrm{PQ}\left(\mathrm{Q}_{\mathrm{A}}\right)$ to the secondary acceptor $\mathrm{PQ}\left(\mathrm{Q}_{\mathrm{B}}\right)$ on the acceptor side of PSII (Baker 2008). ABS/RC is used to measure the size of the apparent antenna (absorption flux of antenna Chl per active RC). Table 3 showed that the value of $\mathrm{ABS} / \mathrm{RC}$ increased under HT stress, suggesting that either the apparent antenna increased its size or a portion of RCs was inactivated. However, we also observed that the value of $\mathrm{TP}_{0} / \mathrm{RC}$ increased, indicating that changes took place both in the apparent antenna size and the RCs. Besides, high humidity improved the decline of quantum yields and efficiencies (e.g., $\varphi_{\mathrm{P} 0}, \varphi_{\mathrm{E} 0}, \delta_{\mathrm{R} 0}$, and $\left.\varphi_{\mathrm{R} 0}\right)$. This means that high humidity might improve the efficiency of photosynthetic electron transport in PSII under HT stress.

The most important biochemical change that occurs when plants are exposed to HT stress is the production of reactive oxygen species (ROS) (Martínez-Téllez and Lafuente 1997). ROS are highly active and reactive, and they can destroy normal metabolism by oxidative damage to proteins, nucleic acids, and lipids without any protective mechanism (Almeselmani et al. 2006). Lipid peroxidation is usually used to detect ROS damage, which clearly reflects the damage of cell membranes caused by abiotic stress ( $\mathrm{Lu}$ et al. 2019). Under stress conditions, the antioxidant defense system of plants is activated to protect cells from the negative effects of ROS (Noctor and Foyer 1998). Our study found that high humidity reduced the contents of MDA and $\mathrm{H}_{2} \mathrm{O}_{2}$ in tomato leaves 


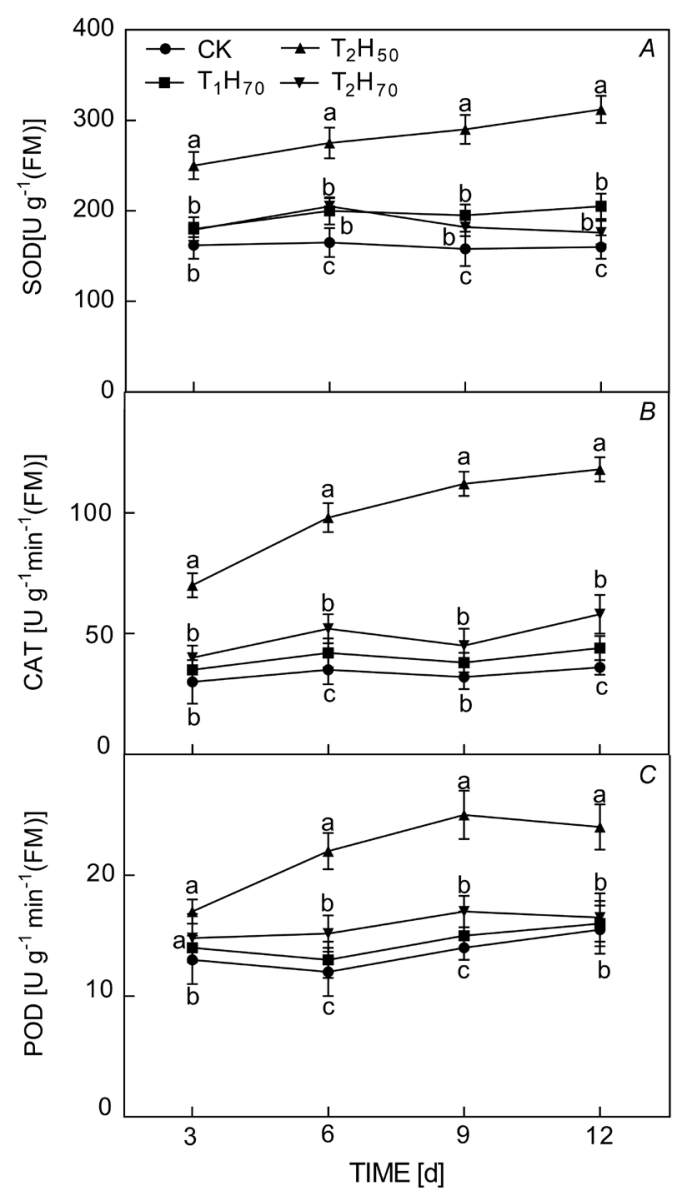

Fig. 4. Effects of high humidity on the activity of catalase (CAT) $(A)$, superoxide dismutase (SOD) $(B)$, and peroxidase (POD) $(C)$ in tomato leaves under HT stress. Different lowercase letters in the same time represent significant differences at the level of 0.05 by Duncan's multiple range tests. Values are means $\pm \mathrm{SD}$, $n=15$. CK $-25 / 15^{\circ} \mathrm{C}+50 \%$ relative humidity $(\mathrm{RH}) ; \mathrm{T}_{1} \mathrm{H}_{70}-$ $25 / 15^{\circ} \mathrm{C}+70 \% \mathrm{RH} ; \mathrm{T}_{2} \mathrm{H}_{50}-38 / 28^{\circ} \mathrm{C}+50 \% \mathrm{RH} ; \mathrm{T}_{2} \mathrm{H}_{70}-38 / 28^{\circ} \mathrm{C}+$ $70 \% \mathrm{RH}$.

compared to the $\mathrm{HT}_{50}$ group (Table 4), and also reduced the activity of SOD, POD, and CAT (Fig. 4), indicating that high humidity might help to alleviate cell membrane peroxidation, scavenge excess ROS, and maintain cell metabolism stability under HT stress.

Therefore, we concluded that high humidity improved the growth and alleviated photoinhibition and oxidative stress of tomato seedlings under heat stress.

\section{References}

Almeselmani M., Deshmukh P., Sairam R. et al.: Protective role of antioxidant enzymes under high temperature stress. - Plant Sci. 171: 382-388, 2006.

Ansari W.A., Atri N., Singh B. et al.: Morpho-physiological and biochemical responses of muskmelon genotypes to different degree of water deficit. - Photosynthetica 56: 1019-1030, 2018.

Apel K., Hirt H.: Reactive oxygen species: metabolism, oxidative stress, and signal transduction. - Annu. Rev. Plant Biol. 55: 373-399, 2004.
Baker N.R.: Chlorophyll fluorescence: a probe of photosynthesis in vivo. - Annu. Rev. Plant Biol. 59: 89-113, 2008.

Barker J.: Effects of day and night humidity on yield and fruit quality of glasshouse tomatoes (Lycopersicon esculentum Mill.). - J. Hortic. Sci. 65: 323-331, 1990.

Berry J., Björkman O.: Photosynthetic response and adaptation to temperature in higher plants. - Ann. Rev. Plant Physio.31: 491-543, 1980.

Camejo D., Rodríguez P., Morales M.A. et al.: High temperature effects on photosynthetic activity of two tomato cultivars with different heat susceptibility. - J. Plant Physiol. 162: 281-289, 2005.

Choudhury S., Panda P., Sahoo L., Panda S.A.: Reactive oxygen species signaling in plants under abiotic stress. - Plant Signal Behav. 8: e23681, 2013.

Cruz De Carvalho M.H.: Drought stress and reactive oxygen species: production, scavenging and signaling. - Plant Signal Behav. 3: 156-165, 2008.

Cruz-Ortega R., Ayala-Cordero G., Anaya A.L.: Allelochemical stress produced by the aqueous leachate of Callicarpa acuminata: Effects on roots of bean, maize, and tomato. Physiol. Plantarum 116: 20-27, 2002.

Das S., Krishnan P., Nayak M. et al.: High temperature stress effects on pollens of rice (Oryza sativa L.) genotypes. Environ. Exp. Bot. 101: 36-46, 2014.

Dhindsa R.S., Matowe W.: Drought tolerance in two mosses: Correlated with enzymatic defence against lipid peroxidation.J. Exp. Bot. 32: 79-91, 1981.

Farquhar G.D., von Caemmerer S., Berry J.A.: Models of photosynthesis. - Plant Physiol. 125: 42-45, 2001.

Fromm J., Lautner S.: Electrical signals and their physiological significance in plants. - Plant Cell Environ. 30: 249-257, 2007.

Gill S.S., Tuteja N.: Reactive oxygen species and antioxidant machinery in abiotic stress tolerance in crop plants. - Plant Physiol. Bioch. 48: 909-930, 2010.

Han W., Yang Z., Huang L. et al.: Fuzzy comprehensive evaluation of the effects of relative air humidity on the morpho-physiological traits of Pakchoi (Brassica chinensis L.) under high temperature. - Sci. Hortic.-Amsterdam 246: 971-978, 2019.

Hodges D.M., DeLong J.M., Forney C.F., Prange R.K.: Improving the thiobarbituric acid-reactive-substances assay for estimating lipid peroxidation in plant tissues containing anthocyanin and other interfering compounds. - Planta 207: 604-611, 1999.

Huang Y.H., Li Y.L., Wen X.Z.: [The effect of different air humidity on vegetative growth of greenhouse tomato under high temperature.]-North. Hortic. 15: 138, 2010. [In Chinese]

Huseynova I.M.: Photosynthetic characteristics and enzymatic antioxidant capacity of leaves from wheat cultivars exposed to drought. - BBA-Bioenergetics. 1817: 1516-1523, 2012.

Krause G., Weis E.: Chlorophyll fluorescence and photosynthesis: The basics. - Annu. Rev. Plant Biol. 42: 313-349, 1991.

Krishnan P., Ramakrishnan B., Reddy K.R., Reddy V.R.: Hightemperature effects on rice growth, yield, and grain quality. Adv. Agron. 111: 87-206, 2011.

Lautner S., Stummer M., Matyssek R. et al.: Involvement of respiratory processes in the transient knockout of net $\mathrm{CO}_{2}$ uptake in Mimosa pudica upon heat stimulation. - Plant Cell Environ. 37: 254-260, 2014.

Li X., Ahammed G., Zhang Y. et al.: Carbon dioxide enrichment alleviates heat stress by improving cellular redox homeostasis through an ABA-independent process in tomato plants. Plant Biol. 17: 81-89, 2015.

Lu T., Yu H., Li Q. et al.: Improving plant growth and alleviating 
photosynthetic inhibition and oxidative stress from low-light stress with exogenous GR24 in tomato (Solanum lycopersicum L.) seedlings. - Front. Plant Sci. 10: 490, 2019.

Marečková M., Barták M., Hájek J.: Temperature effects on photosynthetic performance of Antarctic lichen Dermatocarpon polyphyllizum: a chlorophyll fluorescence study. Polar Biol. 42: 685-701, 2019.

Martínez-Téllez M.A., Lafuente M.T.: Effect of high temperature conditioning on ethylene, phenylalanine ammonia-lyase, peroxidase and polyphenol oxidase activities in flavedo of chilled 〈Fortune〉 mandarin fruit. - J. Plant Physiol. 150: 674-678, 1997.

Maxwell K., Johnson G.N.: Chlorophyll fluorescence a practical guide. - J. Exp. Bot. 51: 659-668, 2000.

Muraoka H., Tang Y., Terashima I. et al.: Contributions of diffusional limitation, photoinhibition and photorespiration to midday depression of photosynthesis in Arisaema heterophyllum in natural high light. - Plant Cell Environ. 23: 235250,2000

Murkowski A.: Heat stress and spermidine: Effect on chlorophyll fluorescence in tomato plants. - Biol. Plantarum 44: 53-57, 2001.

Noctor G., Foyer C.H.: Ascorbate and glutathione: Keeping active oxygen under control. - Annu. Rev. Plant Biol. 49: 249-279, 1998.

Pan C., Ahammed G.J., Li X., Shi K.: Elevated $\mathrm{CO}_{2}$ improves photosynthesis under high temperature by attenuating the functional limitations to energy fluxes, electron transport and redox homeostasis in tomato leaves. - Front. Plant Sci. 9: 1739, 2018.

Peet M.M., Willits D., Gardner R.: Response of ovule development and post-pollen production processes in malesterile tomatoes to chronic, sub-acute high temperature stress. J. Exp. Bot. 48: 101-111, 1997.

Prasad P., Pisipati S., Momčilović I., Ristic Z.: Independent and combined effects of high temperature and drought stress during grain filling on plant yield and chloroplast EF-Tu expression in spring wheat. - J. Agron. Crop Sci. 197: 430-441, 2011.

Pukacka S., Ratajczak E.: Production and scavenging of reactive oxygen species in Fagus sylvatica seeds during storage at varied temperature and humidity. - J. Plant Physiol. 162: 873-885, 2005

Rai A.C., Singh M., Shah K.: Effect of water withdrawal on formation of free radical, proline accumulation and activities of antioxidant enzymes in ZAT12-transformed transgenic tomato plants. - Plant Physiol. Bioch. 61: 108-114, 2012.

Saeed A., Hayat K., Khan A.A., Iqbal S.: Heat tolerance studies in tomato (Lycopersicon esculentum Mill.). - Int. J. Agric. Biol. 9: 649-652, 2007.

Shu S., Tang Y., Yuan Y. et al.: The role of 24-epibrassinolide in the regulation of photosynthetic characteristics and nitrogen metabolism of tomato seedlings under a combined low temperature and weak light stress. - Plant Physiol. Bioch. 107: 344-353, 2016.

Strasser R.J., Srivastava A., Govindjee: Polyphasic chlorophyll a fluorescence transient in plants and cyanobacteria. Photochem. Photobiol. 61: 32-42, 1995.

Strasser R.J., Tsimilli-Michael M., Srivastava A.: Analysis of the chlorophyll $a$ fluorescence transient. - In: Papageorgiou G.C., Govindjee (ed.): Chlorophyll $a$ Fluorescence: A Signature of Photosynthesis. Advances in Photosynthesis and Respiration. Pp. 321-362. Springer, Dordrecht 2004.

Su P., Liu X.: Photosynthetic characteristics of linze jujube in conditions of high temperature and irradiation. - Sci. Hortic.Amsterdam 104: 339-350, 2005.
Su W.C., Sun L.L., Wu R.H. et al.: Effect of imazapic residues on photosynthetic traits and chlorophyll fluorescence of maize seedlings. - Photosynthetica 55: 294-300, 2017.

Sukhov V., Gaspirovich V., Mysyagin S., Vodeneev V.: Hightemperature tolerance of photosynthesis can be linked to local electrical responses in leaves of pea. - Front. Physiol. 8: 763, 2017.

Sukhov V.: Electrical signals as mechanism of photosynthesis regulation in plants. - Photosynth. Res. 130: 373-387, 2016.

Sukhov V., Surova L., Sherstneva O. et al:: Variation potential induces decreased PSI damage and increased PSII damage under high external temperatures in pea. - Funct. Plant Biol. 42: 727-736, 2015.

Sukhova E., Mudrilov M., Vodeneev V., Sukhov V.: Influence of the variation potential on photosynthetic flows of light energy and electrons in pea. - Photosynth. Res. 136: 215-228, 2018.

Surova L., Sherstneva O., Vodeneev V. et al.: Variation potentialinduced photosynthetic and respiratory changes increase ATP content in pea leaves. - J. Plant Physiol. 202: 57-64, 2016.

Tang L., Kwon S.Y., Kim S.H. et al.: Enhanced tolerance of transgenic potato plants expressing both superoxide dismutase and ascorbate peroxidase in chloroplasts against oxidative stress and high temperature. - Plant Cell Rep. 25: 1380-1386, 2006.

Tsimilli-Michael M., Strasser R.J.: In vivo assessment of stress impact on plants' vitality: applications in detecting and evaluating the beneficial role of mycorrhization on host plants. - In: Varma A. (ed.): Mycorrhiza. State of the Art, Genetics and Molecular Biology, Eco-Function, Biotechnology, Eco-Physiology, Structure and Systematics. $3^{\text {rd }}$ edition. Pp. 679-703. Springer, Berlin-Heidelberg 2008.

van der Ploeg A., Heuvelink E.: Influence of sub-optimal temperature on tomato growth and yield: A review. - J. Hortic. Sci. Biotech. 80: 652-659, 2005.

van Kooten O., Snel J.F.H.: The use of chlorophyll fluorescence nomenclature in plant stress physiology. - Photosynth. Res. 25: 147-150, 1990.

Wang L., Yang Z.Q., Wang M.T. et al.: [Effect of air humidity on nutrient content and dry matter distribution of tomato seedlings under high temperature.] - Chin. J. Agrometeorol. 39: 304-313, 2018. [In Chinese]

Wang L., Yang Z.Q., Yang S.Q. et al.: [Effects of high temperature and different air humidity on growth and senescence characteristics for tomato seedlings.] - Chin. J. Agrometeorol. 38: 761-770, 2017. [In Chinese]

Wu M., Kubota C.: Effects of high electrical conductivity of nutrient solution and its application timing on lycopene, chlorophyll and sugar concentrations of hydroponic tomatoes during ripening. - Sci. Hortic.-Amsterdam 116: 122-129, 2008.

Xu C., Yang Z., Wang M. et al.: Effects of low temperature on photosynthesis and antioxidant enzyme activities of Panax notoginseng during seedling stage. - Int. J. Agric. Biol. 21: 1279-1286, 2019.

Yan K., Chen P., Shao H. et al.: Effects of short-term high temperature on photosynthesis and photosystem II performance in sorghum. - J. Agron. Crop Sci. 197: 400-408, 2011.

Yusuf M.A., Kumar D., Rajwanshi R. et al.: Overexpression of $\gamma$-tocopherol methyl transferase gene in transgenic Brassica juncea plants alleviates abiotic stress: Physiological and chlorophyll $a$ fluorescence measurements. - BBABioenergetics 1797: 1428-1438, 2010.

Zaharieva I., Dau H.: Energetics and kinetics of S-state transitions monitored by delayed chlorophyll fluorescence. - Front. Plant Sci. 10: 386, 2019.

Zeliou K., Manetas Y., Petropoulou Y.: Transient winter leaf 
reddening in Cistus creticus characterizes weak (stresssensitive) individuals, yet anthocyanins cannot alleviate the adverse effects on photosynthesis. - J. Exp. Bot. 60: 30313042, 2009.
Zhou R., Yu X., Kjær K.H. et al.: Screening and validation of tomato genotypes under heat stress using $\mathrm{F}_{\mathrm{v}} / \mathrm{F}_{\mathrm{m}}$ to reveal the physiological mechanism of heat tolerance. - Environ. Exp. Bot. 118: 1-11, 2015.

(C) The authors. This is an open access article distributed under the terms of the Creative Commons BY-NC-ND Licence. 